\title{
PELEVELAN PEMAHAMAN KONSEP KOMPOSISI FUNGSI BERDASAR TAKSONOMI SOLO (STRUCTURE OF OBSERVES LEARNING OUTCOMES)
}

\author{
Ulfa Lu'luatul Hidayah ${ }^{1}$, Nur Rohman ${ }^{2}$, Anita Dewi Utami ${ }^{3}$ \\ IKIP PGRI Bojonegoro, ulfaluluatul@gmail.com ${ }^{1}$ \\ IKIP PGRI Bojonegoro, nurrohmanspd83@yahoo.co.id ${ }^{2}$ \\ IKIP PGRI Bojonegoro, anita_dewi@ikippgribojonegoro.ac.id ${ }^{3}$ \\ Received: 13 Agustus 2020, Revised : 13 Oktober 2020, Accepted : 30 Oktober 2020 \\ (C) Mathematics Education Unugiri 2020
}

\begin{abstract}
This qualitative descriptive study aims to describe the level of student understanding of function composition based on the SOLO taxonomy. This research was conducted at Madrasah Aliyah Islamiyah Balen on science class X students school year 2019/2020 with 20 subjects. Sampling using stratified sampling techniques (conditional sample) and purposive sampling (sample aims) see the results of written tests that refer to the grid of test questions and sampling data sources with specific considerations. Analysis of the level of understanding with $\mathrm{PKLM}_{1}, \mathrm{PKLM}_{2}, \mathrm{PKLR}_{1}, \mathrm{PKLR}_{2}, \mathrm{PKLE}_{1}$, and $\mathrm{PKLE}_{2}$. Data analysis using the test method and interview method and test the data's validity using the triangulation of data sources and triangulation of methods. The results showed three levels of students' understanding of the composition of functions based on SOLO taxonomy, namely multi structural, relational, and extended abstract.
\end{abstract}

Keywords: Concept Understanding, Function Composition, SOLO.

\begin{abstract}
Abstrak
Penelitian deskriptif kualitatif ini bertujuan untuk mendeskripsikan level pemahaman siswa pada konsep komposisi fungsi berdasar taksonomi SOLO. Penelitian ini dilakukan di Madrasah Aliyah Islamiyah Balen pada siswa kelas X IPA tahun ajaran 2019/2020 dengan jumlah 20 siswa. Pengambilan sampel menggunakan teknik stratified sampling (sampel bersyarat) dan purposive sampling (sampel bertujuan) yaitu melihat hasil tes tulis yang mengacu pada kisi-kisi soal tes serta pengambilan sampel sumber data dengan pertimbangan tertentu. Analisis level pemahaman dengan subyek $\mathrm{PKLM}_{1}, \mathrm{PKLM}_{2}, \mathrm{PKLR}_{1}, \mathrm{PKLR}_{2}, \mathrm{PKLE}_{1}$, dan $\mathrm{PKLE}_{2}$. Analisis data menggunakan metode tes dan metode wawancara, serta uji keabsahan data menggunakan triangulasi sumber data dan triangulasi metode. Hasil penelitian menunjukkan ada tiga level pemahaman siswa pada konsep komposisi fungsi berdasar taksonomi SOLO yaitu multistruktural, relasional, dan extended abstract.
\end{abstract}

Kata Kunci: Pemahaman Konsep, Komposisi Fungsi, SOLO.

\section{Pendahuluan}

Pendidikan adalah bagian yang penting dalam kehidupan. Pendidikan diperlukan dari lahir hingga saat ini. Pendidikan dapat mencetak sumber daya manusia yang berkualitas dan unggul. Salah satunya pendidikan di bidang matematika. Matematika ilmu pasti yang dominan berkaitan dalam kehidupan sehari - hari. Pemahaman konsep dalam matematika syarat penting yang harus terpenuhi untuk meningkatkan kemampuan kognitif. Menurut Suraji [1] pemahaman konsep adalah kemampuan yang dimiliki seseorang untuk mengemukakan kembali ilmu yang diperolehnya baik dalam bentuk ucapan maupun 
tulisan kepada orang sehingga orang lain tersebut benar-benar mengerti apa yang disampaikan. Pemahaman konsep seseorang dapat diketahui dari pemahaman setiap individu berdasarkan tingkatannya sama halnya seperti pemahaman konsep berdasarkan taksonomi SOLO.

Taksonomi SOLO (Structure of The Observed Learning Outcome) dikembangkan oleh Biggs dan Collis. Taksonomi SOLO digunakan untuk mengukur kemampuan siswa dalam menyelesaikan suatu masalah yang diklasifikasikan menjadi lima tingkatan mulai dari tingkat sederhana sampai tingkat tinggi, Putri [2]. Ada beberapa tingkatan dalam taksonomi SOLO yaitu prastruktural, unistruktural, multistuktural, relasional dan extended abstrack. Di lakukan pra - penelitian untuk mengetahui pemahaman siswa Madrasah Aliyah mengenai konsep komposisi fungsi dengan melevelkan pemahaman siswa berdasar taksonomi SOLO. Berdasarkan hasil tes ada 1 siswa yang memiliki pemahaman dengan tingkat tertinggi pada taksonomi SOLO yaitu tahap extended abstract. Dari Pra Penelitian terdapat level terendah dan juga tertinggi sehingga terindikasi ada. Karena ada maka perlu peneliaain lanjutan untuk mendalami pelevelan pemahaman konsep materi komposisi fungsi. Pentingnya level pemahaman konsep berdasar SOLO untuk membantu guru mengklasifikasikan tingkat pemahaman siswa, sebagai acuan dalam upaya pengembangan proses berpikir siswa. Komposisi fungsi merupakan pemahaman konsep matematika yang sangat penting.

Penelitian ini mendeskripsikan pamahaman kosep siswa berdasarkan level SOLO yang di kaji dalam materi komposisi fungsi pada siswa Sekolah Menengah Atas, sehingga memiliki konsep yang terstruktur dan terarah. Penelitian ini bertujuan untuk melevelkan pemahaman konsep komposisi fungsi berdasar taksonomi SOLO (Structure of Observed Learning Outcomes).

\section{Metode Penelitian}

Penelitian ini menggunakan penelitian kualitatif. Instrumen dalam penelitian ini adalah soal tes dan pedoman wawancara. Soal tes terdiri dari 4 soal dengan masing - masing soal mempunyai nilai tingkatan sesuai dengan levelnya. Subjek dalam penelitian ini berjumlah 20 siswa dari kelas X - IPA. Penelitian ini dilaksanakan di Madrasah Aliyah Islamiyah Balen. Kemudian dari 20 siswa tersebut akan diambil kembali 6 siswa yang memenuhi standar kriteria pelevelan taksonomi SOLO dan memiliki kemampuan komunikasi yang baik dan aktif. Adapun indicator yang diambil adalah seperti yang ditunjukkan oleh Tabel 1

Tabel 1 Indikator Level Taksonomi SOLO Pada Komposisi Fungsi

\begin{tabular}{|c|c|}
\hline $\begin{array}{l}\text { Level Taksonomi } \\
\text { SOLO }\end{array}$ & Indikator \\
\hline $\begin{array}{l}\text { Tingkat } \\
\text { Prastruktural } \\
\text { (Prestructural) }\end{array}$ & $\begin{array}{c}\text { Belum memahami Relasi } \\
\text { Fungsi, Relasi Bukan } \\
\text { Fungsi, Unsur Fungsi, Sifat } \\
\text { - sifat Fungsi, dan } \\
\text { Komposisi Fungsi. }\end{array}$ \\
\hline $\begin{array}{l}\text { Tingkat } \\
\text { Unistruktural } \\
\text { (Unistructural) }\end{array}$ & $\begin{array}{l}\text { Memahami Relasi Fungsi } \\
\text { dan Relasi Bukan Fungsi. } \\
\text { Tidak memahami Unsur } \\
\text { Fungsi, Sifat - sifat Fungsi, } \\
\text { dan Komposisi Fungsi }\end{array}$ \\
\hline $\begin{array}{l}\text { Tingkat } \\
\text { Multistruktural } \\
\text { (Multistructural) }\end{array}$ & $\begin{array}{c}\text { Memahami Relasi Fungsi } \\
\text { dan Unsur Fungsi . } \\
\text { Tidak memahami Sifat - } \\
\text { sifat Fungsi dan Komposisi } \\
\text { Fungsi. }\end{array}$ \\
\hline $\begin{array}{l}\text { Tingkat } \\
\text { Relasional } \\
\text { (Relational) }\end{array}$ & $\begin{array}{l}\text { Memahami Relasi Fungsi, } \\
\text { Unsur Fungsi, dan Sifat - } \\
\text { sifat Fungsi. } \\
\text { Tidak memahami Komposisi } \\
\text { Fungsi. }\end{array}$ \\
\hline $\begin{array}{l}\text { Tingkat Extended } \\
\text { Abstract }\end{array}$ & $\begin{array}{l}\text { Memahami Relasi Fungsi, } \\
\text { Relasi Bukan Fungsi, Unsur } \\
\text { Fungsi, Sifat - sifat Fungsi, } \\
\text { dan Komposisi Fungsi. }\end{array}$ \\
\hline
\end{tabular}

Berdasarkan jawaban dari 20 siswa yang telah dikelompokkan dalam lima level taksonomi SOLO seperti dalam indikator tabel 1 diatas, berikut distribusi jumlah jawaban siswa yang ditunjukkan Tabel 2.

Tabel 2 Sebaran Jumlah Siswa Pada Masing Masing Level Taksonomi SOLO

\begin{tabular}{llc}
\hline No & Taksonomi SOLO & Jumlah siswa \\
\hline 1 & Level Prastruktural & - \\
\hline 2 & Level Unistruktural & - \\
\hline 3 & Level Multistruktural & 10 \\
\hline 4 & Level Relasional & 6 \\
\hline 5 & Level Extended Abstract & 4 \\
\hline
\end{tabular}

Berdasarkan jumlah siswa pada masing masing level ditunjukkan oleh tabel 2, dipilih dua orang untuk diwawancarai setiap level. Pemilihan subjek untuk diwawancarai didasarkan pada kemampuan komunikasi siswa. 


\section{Hasil dan Pembahasan}

Analisis data dilakukan oleh peneliti setelah memperoleh data penelitian dari melakukan tes dan wawancara. Peneliti melakukan tes dima na sebelumnya peneliti telah menyiapkan soal kemudian melakukan validasi soal dan validasi pedoman wawancara. Setelah hasil tes didapatkan, peneliti menimbang dan memilih 6 subjek terpilih untuk diwawancara. Setiap wawancara dalam penelitian ini direkam oleh peneliti dalam bentuk voice record. Voice record yang telah terkumpul kemudian dianalisis dengan cermat dengan memperhatikan hubungan antara hasil tes dan hasil wawancara. Kemudian dari situlah peneliti berhasil menemukan data dalam pengelompokan level taksonomi SOLO terhadap pemamahaman konsep pada materi komposisi fungsi.

Berikut adalah tiga subjek pada tiga jenis level taksonomi SOLO untuk penjelasan masing - masing siswa dalam memahami konsep komposisi fungsi.

\section{Level Multistruktural}

Siswa pada level multistruktural dapat dilihat ketika memahami tentang relasi fungsi dan unsur fungsi, selain itu tidak memahami konsep sifat fungsi dan komposisi fungsi. Hal ini dapat dibuktikan dengan jawaban hasil tes $\mathrm{S} 1$ sebagai berikut :

Soal nomor 1 :

Sudahkah himpunan pasangan berurutan $\{(5,6)$, $(6,3),(7,5),(5,7),(4,6),(8,2)\}$ merupakan relasi fungsi? Jelaskan

Jawab :

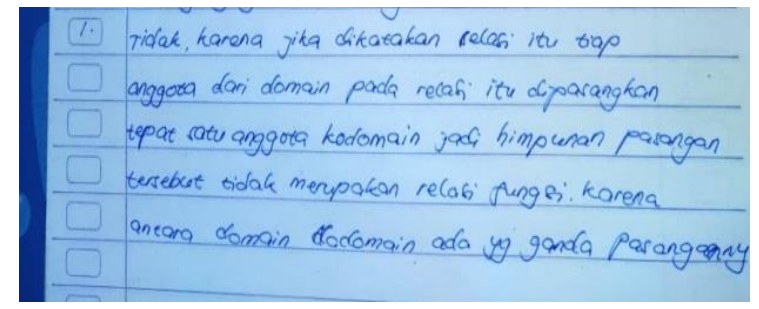

Gambar 1. Jawaban soal 1 S1

S1 nampak memahami mengenenai relasi fungsi, sehingga dapat memahami pula yang dinamakan range pada fungsi. Hal ini dapat ditunjukkan oleh jawaban soal 2.

Soal nomor 2 :

Diketahui $\mathrm{A}=\{x \mid x \leq 4, x \in \mathrm{N}\}$

$\mathrm{B}=\{1,2,3,4,5,6,7,8\}$

Sebuah fungsi $\mathrm{f}: \mathrm{A} \rightarrow \mathrm{B}$ ditentukan oleh $\mathrm{f}(\mathrm{x})=2 \mathrm{x}$

-1 . Tentukan range dari fungsi tersebut!

Jawab :

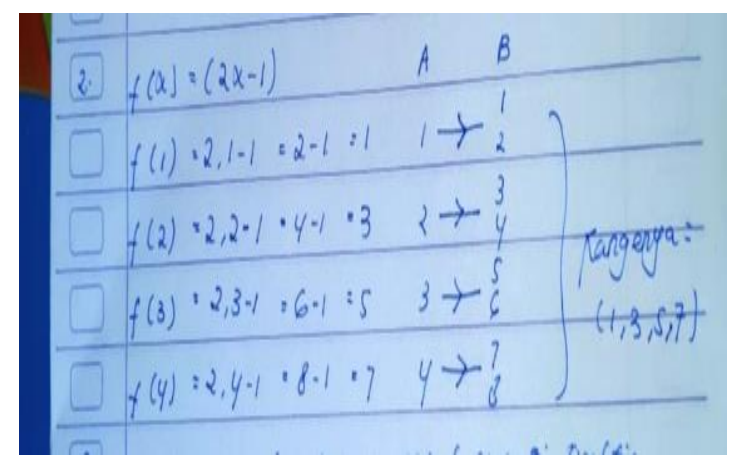

Gambar 2 Jawaban Soal 2 S1

Berdasarkan soal dan jawaban pada gambar 1 dan gambar 2, kondisi seperti ini peneliti memasukkan $\mathrm{S} 1$ berada pada level taksonomi SOLO yaitu multistruktural. Sebab ketika peneliti menanyakan mengenai relasi fungsi dan unsur fungsi seperti range, S1 menjawab dengan tegas dan benar. Kemudian peneliti menanyakan mengenai sifat fungsi dan komposisi fungsi $\mathrm{S}_{1}$ tidak dapat menjawab dengan benar. sehingga $\mathrm{S} 1$ tidak memahami sifat - sifat fungsi dan konsep komposisi fungsi.

\section{Level Relasional}

Siswa pada level taksonomi ini sudah memahami relasi fungsi, unsur - unsur fungsi, sifat sifat fungsi. Bahkan melalui percakapan wawancara yang ditanyakan oleh peneliti, S2 sudah mulai memahami sifat-sifat fungsi terbukti sebelum mengerjakan soal nomor 3 yaitu soal nomor 1 dan 2 sudah benar. Jawaban soal nomor 5 pun menunjukkan bahwa $\mathrm{S} 2$ bisa memahami sifat- sifat fungsi yaitu sifat bijektif.

Hanya dalam pengerjaannya masih belum benar dalam mengerjakan komposisi fungsi. Hal ini dapat ditunjukkan dari gambar 3, gambar 4 dan gambar 5 .

Soal nomor 1:

Sudahkah himpunan pasangan beruruta $\{(5,6),(6,3),(7,5),(5,7),(4,6),(8,2)\} \quad$ merupakan relasi fungsi? Jelaskan

Jawab :

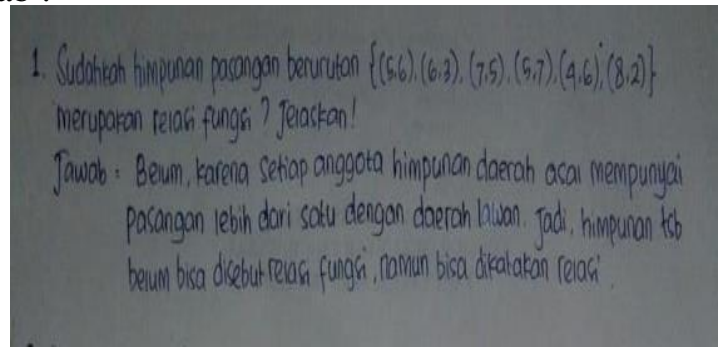

Gambar 3. Jawaban Soal 1 S2 
Nampak pada Gambar 3 bahwa S2 sudah memahami relasi fungsi dan dapat menjelaskan mengenai unsur - unsur fungsi. Hal ini dapat ditunjukkan pada soal no 2 .

Soal nomor 2 :

Diketahui $\mathrm{A}=\{x \mid x \leq 4, x \in \mathrm{N}\}$

$$
\mathrm{B}=\{1,2,3,4,5,6,7,8\}
$$

Sebuah fungsi $\mathrm{f}: \mathrm{A} \rightarrow \mathrm{B}$ ditentukan oleh $f(x)=2 x$ -1 . Tentukan range dari fungsi tersebut !

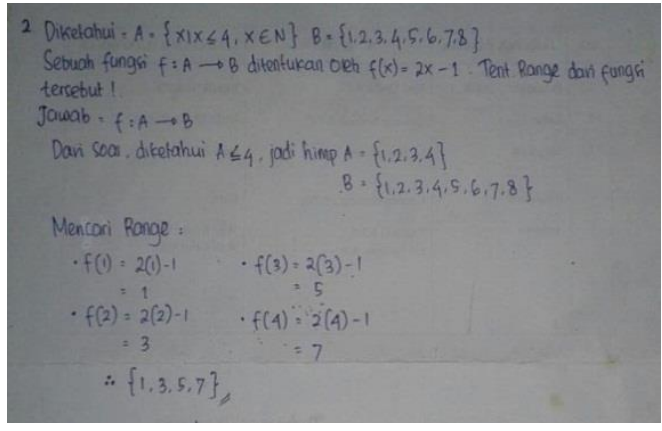

Gambar 4 Jawaban Soal 2 S2

S2 dapat memahami tentang unsur - unsur fungsi. Dapat dilihat dari S2 menyelesaikan permasalahan dengan jawaban benar. Sehingga tidak menutup kemungkinan dapat memahami tentang sifat - sifat fungsi. Hal ini seperti dipaparkan pada jawaban soal nomor 3 .

Soal nomor 3 :

Perhatikan gambar dibawah ini
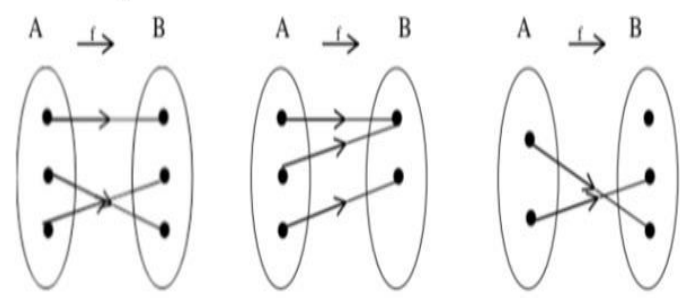

Manakah yang termasuk fungsi bijektif? Jelaskan. Jawab :

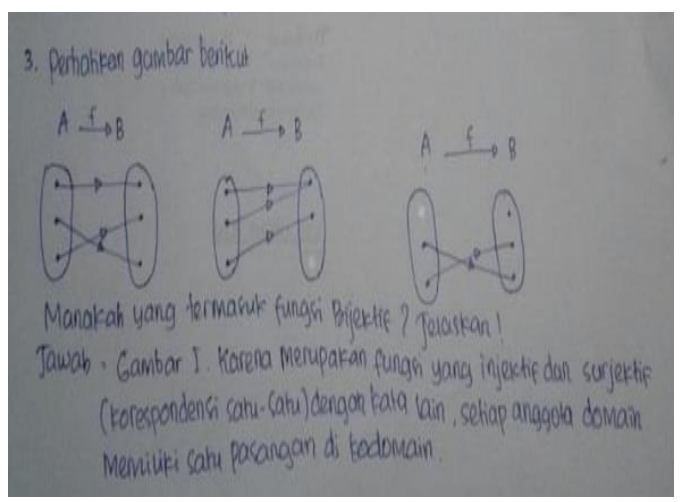

Gambar 5. Jawaban Soal 3 S2
S2 terlihat dapat menyelesaikan mengenai sifat - sifat fungsi dengan benar. Sehingga dapat dikatakan bahwa S2 sudah memahami sifat - sifat fungsi.

Berdasarkan jawaban di atas terlihat bahwa benar S2 sudah memahami relasi fungsi, unsur unsur fungsi, dan sifat - sifat fungsi. Meskipun jawaban nomor 4 S2 salah, S2 sudah benar dalam mengerjakan soal nomor 1 sampai 3 membuktikan bahwa S2 berada pada level Relasional. Terbukti saat wawancara S2 hanya dapat menjelaskan pegertian relasi fungsi, cara menentukan range, dan menjelaskan dari fungsi bijektif.

\section{Level Extended Abstract}

Siswa pada level taksonomi SOLO ini sudah memahami dengan baik dan benar dalam pengerjaan materi yang berkaitan dengan relasi fungsi, unsur unsur fungsi, sifat - sifat fungsi dan komposisi fungsi. Hal ini dapat ditunjukkan oleh gambar 6,7,8 dan 9.

Soal nomor 1:

Sudahkah himpunan pasangan berurutan $\{(5,6),(6,3),(7,5),(5,7),(4,6),(8,2)\} \quad$ merupakan relasi fungsi? Jelaskan

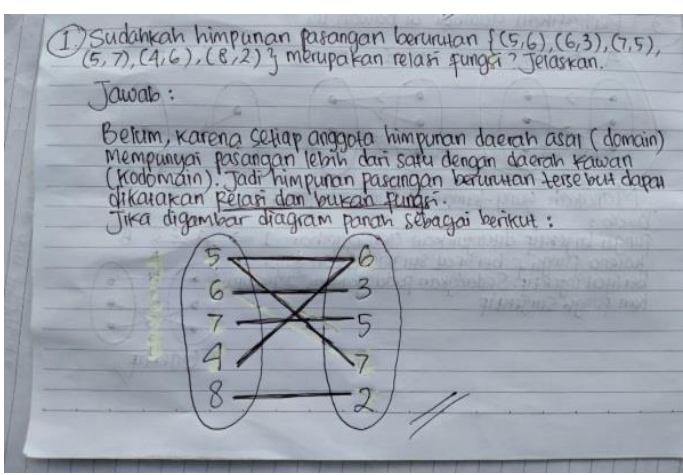

Gambar 6 Jawaban Soal 1 S3

Dapat dilihat dari jawaban S3 terlihat bahwa sudah memahami relasi fungsi. Dapat dibuktikan juga dengan jawaban wawancara bahwa untuk mempertegas jawaban dengan menggambarkan diagram panah. S3 juga mengetahui tentang domain, kodomain dan range. Hal ini dapat dilihat dari jawaban soal nomor 2.

Soal nomor 2 :

Diketahui $\mathrm{A}=\{x \mid x \leq 4, x \in \mathrm{N}\}$

$$
\mathrm{B}=\{1,2,3,4,5,6,7,8\}
$$

Sebuah fungsi $\mathrm{f}: \mathrm{A} \rightarrow \mathrm{B}$ ditentukan oleh $f(x)=$ $2 x-1$. Tentukan range dari fungsi tersebut! 


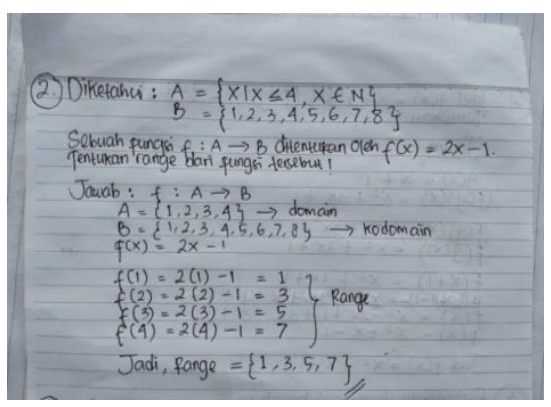

\section{Gambar 7 Jawaban Soal 2 S3}

Berdasarkan jawaban diatas, menunjukkan bahwa sudah memahami sifat fungsi dengan benar dan konsisten. Selain itu S3 juga menjelaskan dengan runtut dan benar dalam cara pengerjaanya sehingga mendapatkan hasil dari range. Kemudian menggeneralisasikan untuk menyelesaikan soal mengenai sifat - sifat fungsi. Hal ini ditunjukkan soal nomor 3

Soal nomor 3 :

Perhatikan gambar dibawah ini.
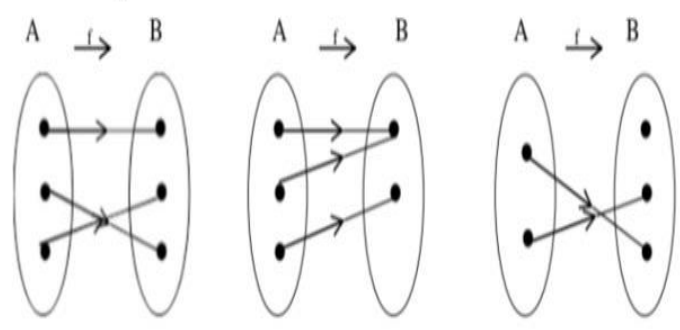

Manakah yang termasuk fungsi bijektif? Jelaskan.

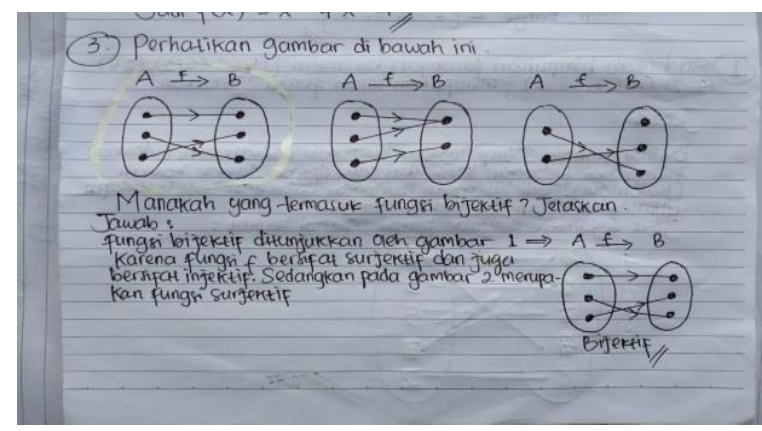

\section{Gambar 8 Jawaban Soal 3 S3}

Pada jawaban diatas ditunjukkan PKLE 1 menjelaskan dengan benar dan tepat. Setelah memahami konsep fungsi dapat menyelesaikan persoalahan tentang konsep komposisi fungsi dengan melihat pada jawaban soal nomor 4 .

Soal nomor 4 :

Jika $g(x)=x+1$ dan $(f \circ g)(x)=x^{2}+3 x+1$. Tentukan $f(x)$ !

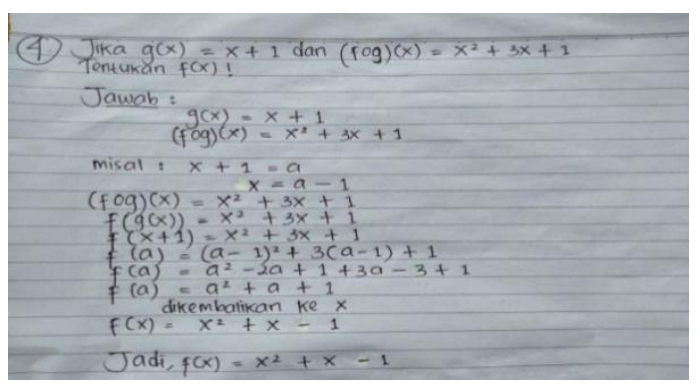

Gambar 9 Jawaban Soal 4 S3

Berdasarkan jawaban dari soal nomor 1, 2, 3 dan 4 S3 mampu mengerjakan masalah dengan memahami relasi fungsi, unsur fungsi, sifat fungsi dan komposisi fungsi. Maka, kondisi ini membawa S3 berada pada level paling sempurna yaitu level extended abstract pada pemahaman konsep komposisi berdasar taksonomi SOLO.

Penelitian ini dilakukan dengan tujuan untuk melevelkan pemahaman siswa pada konsep komposisi fungsi. Wibawa [3] mengembangkan lima level taksonomi SOLO tersebut berdasarkan tingkatan taksonomi SOLO menurut Biggs dan Collis. Berikut penjabaran level pemahaman konsep komposisi fungsi berdasar taksonomi SOLO pada gambar 10 berikut ini :

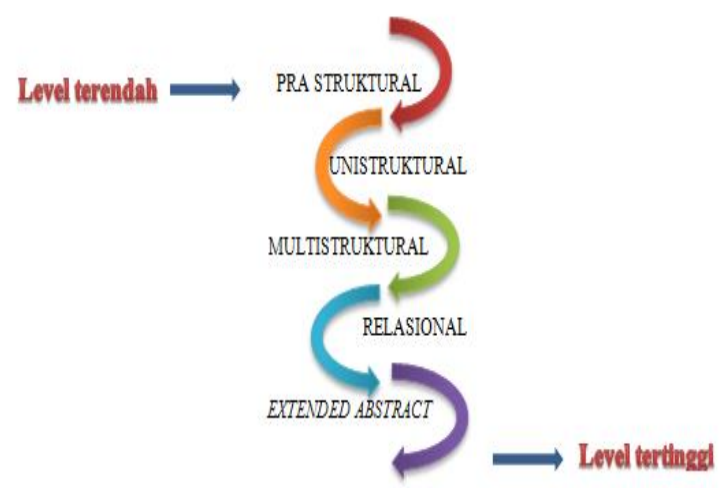

\section{Gambar 10 Pelevelan Pemahaman Konsep Komposisi Fungsi Berdasar Taksonomi SOLO}

Berdasarkan bagan 4.1 tersebut, berikut dijelaskan lebih lanjut mengenai level taksonomi SOLO siswa sesuai dengan hasil penelitian 20 siswa dalam memahami konsep komposisi.

Siswa yang berada di level pra struktural sama sekali tidak mengetahui konsep relasi fungsi, unsur fungsi, sifat fungsi dan komposisi fungsi. Pada saat peneliti melakukan penelitian, peneliti tidak menemukan siswa masuk dalam level ini, sehingga dalam penelitian level ini tidak diambil untuk 
dijadikan subjek. Hal ini juga sama seperti penelitian yang di lakukan Sutomo [4] bahwa tidak ada siswa pada level prastruktural dalam memahami konsep himpunan.

Siswa yang berada di level unistruktural dapat memahami relasi fungsi. Akan tetapi tidak mampu memahami dari unsur fungsi, sifat fungsi dan komposisi fungsi. Pada saat peneliti melakukan penelitian, penelitian tidak menemukan siswa yang masuk dalam level ini. Sehingga peneliti juga tidak mengambil subjek pada level ini. Pada dasarnya pada tingkatan ini semua siswa sudah memahami dengan baik dengan hanya mengetahui satu informasi / konsep yang diperoleh. Pesona [5] menyatakan bahwa siswa dapat menggunakan satu penggal informasi dalam merespons suatu data tunggal.

Siswa yang berada di level multistruktural dapat memahami relasi fungsi dan unsur fungsi, akan tetapi mereka masih belum memahami mengenai sifat fungsi dan komposisi fungsi. Pada saat peneliti melakukan penelitian, peneliti menemukan 10 siswa masuk dalam level ini. Kesepuluh siswa ini hampir semuanya hanya benar dalam pengerjaan dua soal dari 4 butir soal tes yang diberikan. Setelah peneliti amati bahwa dua subjek terpilih yang peneliti jadikan sebagai perwakilan dari kesepuluh anak tersebut. Ternyata masing - masing dari mereka sebenarnya sudah memahami relasi fungsi dan unsur fungsi akan tetapi mereka masih belum bisa mampu berada lebih tinggi pada level ini. Sejalan dengan Wibawa [3] yang menyatakan bahwa level multistruktural siswa mampu menggunakan beberapa informasi yang bersifat terpisah, serta dapat membuat hubungan dari informasi tersebut. Dalam penelitian Wibawa [3] siswa mampu menggunakan konsep anggota himpunan serta mampu menghubungkan dengan konsep irisan namun masih ada kesalahan dalam menghubungkan dengan konsep gabungan.

Siswa yang berada di level relasional dapat memahami relasi fungsi, unsur fungsi, dan sifat fungsi. Akan tetapi belum bisa memahami komposisi fungsi. Pada saat peneliti melakukan penelitian, peneliti menemukan 6 siswa yang masuk dalam level ini. Keenam siswa ini telah berhasil mengerjakan tiga soal dari 4 butir soal yang diberikan. Setelah peneliti amati bahwa dua subjek terpilih yang peneliti jadikan subjek sebagai perwakilan dari keenam siswa tersebut, ternyata masing - masing dari mereka sebenarnya memahami relasi fungsi, unsur fungsi dan sifat fungsi, namun masih belum memahami komposisi fungsi karena masih terdapat siswa kurang teliti dan konsisten dalam memahami konsep komposisi fungsi. Sesuai dengan pernyataan Hasan [6] bahwa siswa dapat menggunakan beberapa data atau lebih dari dua yang termuat dalam teks soal kemudian mengaplikasikan konsep dan dapat menarik kesimpulan relevan.

Siswa yang berada di level extended abstract dapat memahami relasi fungsi, unsur fungsi, sifat fungsi dan komposisi fungsi dengan sempurna. Pada saat peneliti melakukan penelitian, peneliti menemukan 4 siswa masuk dalam level ini. Kempat siswa ini telah berhasil mengerjakan 4 butir soal yang diberikan dengan sempurna. Setelah peneliti amati bahwa dua subjek terpilih yang peneliti jadikan sebagai perwakilan dari empat siswa tersebut., ternyata masing - masing dari mereka benar - benar telah memahami konsep relasi fungsi, unsur fungsi, sifat fungsi hingga konsep komposisi fungsi. Serta konsisten dengan baik dan benar dalam mengerjakan soal - soal yang diberikan. Subjek yang berhasil masuk level extended abstrak ini dapat dikatakan sebagai subjek yang sempurna dalam pemahaman dan termasuk subjek yang dapat berpikir tingkat tinggi sebab dapat memecahkan masalah (soal tes uraian) dengan sempurna. Dewanto dalam Amalia [7] menyatakan bahwa kemampuan berpikir tingkat tinggi adalah suatu kapasitas diatas informasi yang diberikan, dengan sikap yang kritis untuk mengevaluasi, mempunyai kesadaran (awereness) metakognitif dan memiliki kemampuan pemecahan masalah.

Berdasarkan penelitian yang telah dilakukan, peneliti memaparkan beberapa temuan terkait level pemahaman siswa pada konsep komposisi fungsi berdasar taksonomi SOLO yaitu siswa berada pada level extended abstract , relasional, dan multistruktural, serta tidak ada siswa yang berada pada level prastruktural dan unistruktural. Hal ini sejalan dengan teori APOS yaitu kegiatan mental seorang anak yang berbentuk aksi, proses, objek dan skema (Astuti [8]). Berdasarkan teori APOS siswa pada tingkatan SMA yang sederajat dengan MA bahwa siswa sudah dapat mengkontruksikan yang mengaitkan aksi, proses dan objek sehingga mampu menentukan hasil seseuai dengan permasalahan yang diberikan. Siswa juga dapat memberikan kesimpulan langkah untuk menyelesaikan masalah. Hal ini menunjukkan bahwa pemahaman siswa mencapai tahap level multistruktural.

Penelitian Sutomo [4] menunjukkan bahwa untuk siswa diatas KKM memiliki rata rata $20 \%$ pada level extended abstract, $90 \%$ pada level relasional, $70 \%$ pada level multistruktural, $20 \%$ 
pada unistruktural dan $0 \%$ untuk level prastruktural. Sementara untuk siswa dibawah KKM memiliki rata rata $0 \%$ pada level extended abstract, $0 \%$ pada level relasional, $10 \%$ pada level multistruktural, $70 \%$ pada level unistruktural, dan $40 \%$ untuk level prastruktural. Dari hal tersebut deskrispi level taksonomi solo terhadap pemahaman konsep matematika pada siswa yang memperoleh skor diatas KKM dalam kategori kurang baik dan pemahaman konsep matematika pada siswa yang memperoleh skor dibawah KKM dalam kategori tidak baik.

Hasil penelitian Wibawa [3] menunjukkan ada lima level taksonomi SOLO dalam analisis pememahaman konsep matematis siswa menyelesaikan soal materi himpunan yaitu pra struktural, unistruktural, multistruktural, relasional dan extended abstract. Pada penelitian ini, peneliti melakukan penelitian dengan pedoman pada lima level taksonomi SOLO yang dijabarkan oleh Wibawa [3]. Penelitian terdahulu mengambil materi pemahaman himpunan, sedangkan materi dalam penelitian ini adalah pemahaman konsep komposisi fungsi.

\section{Penutup}

Berdasarkan data, informasi, analisis data dan pembahasan yang dilakukan oleh peneliti maka dapat peneliti mendeskripsikan beberapa level pemahaman siswa pada konsep komposisi fungsi berdasar taksonomi SOLO, yaitu level taksonomi SOLO yang ketiga ialah level multistruktural, menunjukkan bahwa siswa dapat memahami dari beberapa konsep yang diberikan saling berkaitan dengan baik dan benar dalam mengerjakan materi relasi fungsi. Siswa juga mulai memahami unsur fungsi. Akan tetapi tidak bisa mengerjakan soal memahami sifat fungsi dan komposisi fungsi. Level taksonomi SOLO yang keempat adalah level relasional, menunjukkan siswa sudah memahami relasi fungsi, unsur fungsi, dan sifat fungsi dengan baik dan benar dengan mengetahui konsep yang sebelumnya sehingga dapat menarik kesimpulan yang relevan. Terakhir adalah level extended abstract, dimana siswa dapat dikatakan sempurna dalam pemahaman. Karena dalam model ini siswa sudah mampu memahami dengan baik dan benar dalam pengerjaan materi yang berkaitan dengan relasi fungsi, unsur fungsi, sifat fungsi dan komposisi fungsi.

Adapun tingkat pemahaman yang dimiliki masing-masing siswa berbeda-beda, hal tersebut dapat dipicu dari beberapa hal, antara lain kemampuan berpikir, kecerdasan intelektual, kurangnya ketelitian, kurangnya pemahaman dalam materi dan lain sebagainya. Hal tersebut membuat perbedaan tingkatan pemahaman siswa, sehingga dilevelkan sesuai dengan level taksonomi SOLO menurut Hayuhantika [9] kelima tingkatan tersebut berturut turut dari yang paling rendah yaitu prastructural, unistructural, multistructural, relational, dan extended abstract.

Hasil penelitian yang diperoleh terdapat 3 pasang subjek pilihan yang mewakili ranah level taksonomi SOLO pada materi komposisi fungsi tersebut memiliki hasil jawaban pada tes tulis yang benar dan sesuai dengan hasil data wawancara sehingga diperoleh data yang valid.

\section{Referensi}

[1] Suraji, Maimunah, dan Sehatta Saragih. 2018. Analisis Kemampuan Pemahaman Konsep Matematis dan Kemampuan Pemecahan Masalah Matematis Siswa SMP pada Materi Sistem Persamaan Linear Dua Variabel (SPLDV). Suska Journal of Mathematics Education, 4 (1): 9-16.

[2] Putri, D. A. K., dan Suparji. 2014. Analisis Kesalahan Siswa dalam Menyelesaikan Soal yang Berhubungan dengan Konstruksi Statis Tertentu Berdasarkan Taksonomi SOLO Plus pada KelasX TGB SMK Negeri 3 Surabaya. Jurnal Kajian Pendidikan Teknik Bangunan, 3 (1): 59-66.

[3] Wibawa, H,. \& Masduki, S. S. 2017. Analisis Pemahaman Konsep Matematika Siswa Dalam Menyelesaikan Soal Materi Himpunan Berdasarkan Taksonomi Solo (Structure Of Observed Learning Outcomes) Pada Siswa Kelas VII SMP Negeri 2 Baki (doctoral dissertation, universitas muhammadiyah Surakarta.

[4] Sutomo, W. A. B., \& Sutira, S. 2019. Analisis Kemampuan Pemahaman Konsep Matematika Berdasar Taksonomi SOLO (Structure of Observed Learning Outcomes) Pada Soal Materi Himpunan di SMP N 2 karawang barat. Prosiding sesiomadika, 2(5).

[5] Pesona, R. I., \& Yunita, T. N. H. 2018. Deskripsi Kemampuan Matematika Siswa Dalam Pemecahan Masalah Sistem Persamaan Linear Dua Variabel Berdasarkan Level Taksonomi SOLO. Genta Mulia: Jurnal Ilmiah Pendidikan, 9(1), 99-109

[6] Hasan, B. 2017. Karakteristik Respon Siswa Dalam Menyelesaikan Soal Geometri Berdasarkan Taksonomi SOLO. JINoP(Jurnal inovasi pembelajaran), 3(1), 449-458.

[7] Amalia, R. 2016. Kemampuan Berpikir Matematis Mahasiswa Dalam Menyelesaikan Masalah 
Geometri. EDUT-MAT:Jurnal Pendidikan Matematika, 4(2), 118 -125.

[8]

Astuti, D., Usodo, B., \& Aryuna, D. R. (2017). Profil Pemahaman Siswa Sekolah Menengah Atas (SMA) Pada Materi Turunan Berdasarkan Teori APOS Ditinjau dari Gaya Belajar Kognitif Siswa. Jurnal Pendidikan Matematka Dan Matematika (JPMM) Solusi, 1(5), 37-47.

[9] Hayuhantika, D. 2016. Pemetaan Respon Siswa Smp Berdasarkan Taksonomi Solo Dalam Penyelesaian Masalah Generalisasi Pola. JP2M (Jurnal Pendidikan dan Pembelajaran Matematika), 2(2), 92-105. 